\title{
PENGARUH DISIPLIN KERJA DAN KOMUNIKASI TERHADAP KINERJA PEGAWAI PADA KANTOR BADAN PERTAHANAN NASIONAL (BPN) KOTA PEMATANGSIANTAR
}

\author{
Oleh: \\ Gita Theresia Ambarita \\ S1 Manajemen \\ Darwin Lie, Efendi, Sisca
}

Tujuan penelitian ini adalah: 1. Untuk mengetahui gambaran disiplin kerja, komunikasi dan kinerja pegawai pada Kantor Badan Pertanahan Nasional (BPN) Kota Pematangsiantar. 2. Untuk mengetahui pengaruh disiplin kerja dan komunikasi terhadap kinerja pegawai pada Kantor Badan Pertanahan Nasional (BPN) Kota Pematangsiantar secara simultan dan parsial.

Penelitian ini dilakukan dengan menggunakan desain penelitian kepustakaan dan lapangan. Sedangkan jenis data yang digunakan yaitu data kualitatif dan data kuantitatif. Sumber data menggunakan data primer dan data sekunder. Adapun populasi pada penelitian ini pegawai Kantor Pertanahan Nasional (BPN) Kota Pematangsiantar sejumlah 31 orang. Pengumpulan data dilakukan dengan wawancara, kuesioner dan dokumentasi. Teknik analisis yang digunakan adalah regresi linear berganda, koefisien korelasi, koefisien determinasi dan pengujian hipotesis dengan uji F serta uji t.

Hasil penelitian dapat disimpulkan sebagai berikut: 1. Disiplin kerja, komunikasi dan kinerja pegawai dengan kriteria sudah baik. 2. Hasil analisis regresi adalah $\hat{Y}=34,319+0,445 X_{1}+0,638 X_{2}$ berarti disiplin kerja dan komunikasi berpengaruh positif terhadap kinerja pegawai. 3. Hasil analisis korelasi diperoleh nilai $r=0,826$ artinya terdapat hubungan yang sangat kuat dan positif antara disiplin kerja dan komunikasi dengan kinerja pegawai. Selanjutnya diperoleh koefisien determinasi $(R)=0,682$ artinya tinggi rendahnya kinerja pegawai dapat dijelaskan sebesar $68,2 \%$ oleh disiplin kerja dan komunikasi. 4. Hipotesis $\mathrm{H}_{0}$ ditolak, artinya disiplin kerja dan komunikasi berpengaruh positif dan signifikan terhadap kinerja pegawai secara simultan dan parsial.

Adapun saran dari hasil penelitian ini adalah 1. untuk meningkatkan disiplin kerja, pimpinan harus lebih tegas memberikan sanksi bagi siapa saja yang melanggar aturan. 2. Untuk mempengaruhi komunikasi, pimpinan maupun para bawahan harus berusaha menciptakan hubungan baik agar dapat tercapainya lingkungan kerja yang kondusif. 3. untuk mengoptimalkan kinerja pegawai, pimpinan harus menerapkan peraturan yang berlaku agar pegawai dapat melaksanakan peraturan tersebut dengan baik.

Kata kunci: Disiplin Kerja, Komunikasi dan Kinerja Pegawai

\section{Abstraction}

The purpose of this study are: 1. To determine the description of work discipline and communication and the employee's performance at Kantor Badan Pertanahan Nasional (BPN) Kota Pematangsiantar. 2. To determine the influence of work discipline and communication on employee's performance at Kantor Badan Pertanahan Nasional (BPN) Kota Pematangsiantar simultaneously and partially.

This research is done with library research and field research. The data types are cualitative and quantitative data, the data sources are primer and secondary data. The population in this research is as much as 31 respondents. The data collection is done with questionnaire, interview and documentation. Technical analysis used is multiple linear regression, coefficient of correlation, coefficient of determination and hypothesis test $F$ test and test.

The results of the study can be summarized as follows: 1. work discipline, communication and employee's performance is good. 2. The results of regression analysis is $\hat{\mathrm{Y}}=34,319+0,445 \mathrm{X}_{1}+0,638 \mathrm{X}_{2}$ it means that work discipline and communication had a positive influence on employee's performance. 3. The results of correlations analysis get value $r=0,826$, it means that there is a high and positive correlation between work discipline, communication with employee's performance. Further obtained coefficient of determination $(\mathrm{R})=0.682$ means the level of employee's performance can be explained as much as 68,2\% by work discipline and communication. 4. The results of hypothesis test $\mathrm{HO}$ is rejected, it means that work discipline and communication had a positive and significant influence on employee's performance simultaneously and partially.

The suggestion of this research is to improve the work discipline, 1. the leadership must be more firmly to give sanction for anyone who violates the rules. 2. To influence communication, the leadership and the subordinates must create good relations in order to achieve a conducive working environment. 3. to optimize the employee's performance, the leadership have to apply the rules so that employees can implement the rules properly.

Keywords: Work Discipline, Communication and Employee's Performance 


\section{A. PENDAHULUAN}

\section{Latar Belakang Masalah}

Kantor Badan Pertanahan Nasional (BPN) yaitu lembaga Pemerintah Non Departemen yang berada di bawah Kementrian Agraria dan Tata Ruang dan bertanggung jawab kepada Presiden dan dipimpin oleh Kepala (sesuai dengan Perpres No. 63 Tahun 2013). Badan Pertanahan Nasional mempunyai tugas melaksanakan tugas pemerintahan di bidang pertanahan secara nasional, regional dan sektoral sesuai dengan ketentuan peraturan perundangundangan.

Keberhasilan suatu organisasi sangat dipengaruhi oleh kinerja pegawainya. Setiap organisasi akan selalu berusaha untuk meningkatkan kinerja pegawai dengan harapan apa yang menjadi tujuan organisasi akan tercapai. Dimensi kinerja pada Kantor Badan Pertanahan Nasional (BPN) Kota Pematangsiantar diketahui berdasarkan Sasaran Kinerja Pegawai (SKP) serta Perilaku Kerja (PK). Adapun fenomena kinerja pegawai pada Kantor Badan Pertanahan Nasional (BPN) Kota Pematangsiantar adalah sebagai berikut:

Salah satu faktor yang mempengaruhi kinerja pegawai adalah disiplin kerja. Seorang pegawai dikatakan disiplin jika menaati waktu kerja, mengikuti apel, melakukan apel, melakukan pekerjaan dengan baik, serta mematuhi peraturan yang sudah ditetapkan. Penerapan disiplin kerja tertulis dalam PP Nomor 53 Tahun 2010 tentang pegawai negeri sipil memiliki kewajiban yang harus dijalankan dan larangan-larangan yang harus dijauhi agar terwujud disiplin kerja yang baik. Disiplin kerja di Kantor Badan Pertanahan Nasional (BPN) Kota Pematangsiantar masih belum optimal, terlihat dari adanya beberapa pegawai yang masih melanggar peraturan secara berulang terutama dalam hal memanfaatkan waktu kerja, tingkat kehadiran pegawai yang mengikuti apel pagi dan sore tidak lebih dari $70 \%$ dari seluruh jumlah pegawai, serta banyaknya pegawai yang terlambat datang kantor ataupun tidak hadir.

Selain disiplin, faktor lain yang dapat mempengaruhi kinerja pegawai adalah komunikasi Komunikasi sangatlah penting dalam kemajuan suatu organisasi. Komunikasi yang digunakan Kantor Badan Pertanahan Nasional (BPN) Kota Pematangsiantar adalah komunikasi ke bawah, komunikasi ke atas, komunikasi horizontal, dan komunikasi diagonal. Komunikasi ke bawah yaitu penyampaian informasi yang mengalir dari atasan kepada bawahan, bertujuan agar para pemimpin lebih mudah dalam pengambilan keputusan Komunikasi ke atas yaitu informasi yang berasal dari bawahan ke atasan. Komunikasi ke atas digunakan dalam pengajuan usul dan saran, keluhan, pengaduan, dan penetapan sasaran dengan penetapan management by objective (MBO).

Komunikasi horizontal yaitu komunikasi yang digunakan di dalam tim, diantara kepala seksi dan diantara pengkoordinasi dan peranan penghubung, dapat membantu orang-orang untuk mengkoordinasikan proyek, menyelesaikan masalah, dan memecahkan konflik-konflik. Komunikasi diagonal yaitu komunikasi antara pimpinan seksi dengan pegawai seksi lain, seperti anggota staf junior dapat langsung pergi ke atasannya melalui telpon, email, atau mengunjungi tekhnikal senior di area lain untuk mendapatkan informasi.

Kantor Badan Pertanahan Nasional (BPN) Kota Pematangsiantar mengelola komunikasi sebagai upaya menghasilkan kinerja pegawai yang optimal. Fenomena komunikasi pada Kantor Badan Pertanahan Nasional (BPN) Kota Pematangsiantar terlihat pada hubungan kerja para pegawai yang kurang harmonis disebabkan oleh jalinan komunikasi yang kurang baik, dimana setiap pegawai memiliki kesibukan tersendiri sehingga menyebabkan kurangnya untuk saling berkomunikasi.

Berdasarkan latar belakang di atas, maka penulis tertarik untuk melakukan penelitian dengan judul: Pengaruh Disiplin Kerja dan Komunikasi Terhadap Kinerja Pegawai pada Kantor Badan Pertanahan Nasional (BPN) Kota Pematangsiantar.

\section{Rumusan Masalah}

Berdasarkan latar belakang permasalahan di atas dapat ditarik perumusan masalah sebagai berikut:

1. Bagaimana gambaran disiplin kerja, komunikasi dan kinerja pegawai pada Kantor Badan Pertanahan Nasional (BPN) Kota Pematangsiantar.

2. Bagaimana pengaruh disiplin kerja dan komunikasi terhadap kinerja pegawai pada Kantor Badan Pertanahan Nasional (BPN) Kota Pematangsiantar baik secara simultan maupun parsial.

3. Tujuan Penelitian

Adapun tujuan penelitian ini adalah sebagai berikut:

1. Untuk mengetahui gambaran disiplin kerja, komunikasi dan kinerja pegawai pada Kantor Badan Pertanahan Nasional (BPN) Kota Pematangsiantar.

2. Untuk mengetahui pengaruh disiplin kerja dan komunikasi terhadap kinerja pegawai pada Kantor Badan Pertanahan Nasional (BPN) Kota Pematangsiantar baik secara simultan maupun parsial.

\section{Metode Penelitian}

Yang menjadi objek penelitian dalam hal ini adalah pegawai Kantor Badan Pertanahan Nasional (BPN) Kota Pematangsiantar yang terletak di jalan Dahlia No. 8 Kelurahan Bah Kapul Kecamatan Pematangsiantar, Sumatera Utara. Semua popoulasi pegawai Kantor Badan Pertanahan Nasional (BPN) Kota Pematangsiantar adalah 31 orang yang sekaligus dijadikan sampel dalam penelitian ini.

Adapun Desain penelitian yang digunakan dalam penulisan skripsi ini adalah Penelitian Kepustakaan (Library Research) dan Penelitian Lapangan (Field Research). Teknik pengumpulan data yang dilakukan penulis dalam penelitian ini 
adalah berupa Kuesioner, Wawancara, Dokumentasi dan Observasi. Adapun jenis data yang digunakan dalam penelitian ini adalah jenis data kualitatif dan data kuantitatif. Hasil data yang diperoleh dari lapangan akan dianalisis secara deskriptif baik bersifat kualitatif dan kuantitatif.

\section{B. LANDASAN TEORI}

\section{Manajemen Sumber Daya Manusia}

Adapun pengertian tentang manajemen sumber daya manusia ditulis beberapa ahli manajemen yang pada dasarnya memiliki kesimpulan yang sama. Manajemen sumber daya manusia merupakan salah satu manajemen yang menitikberatkan perhatiannya terhadap masalah yang berhubungan dengan kepegawaian dalam sebuah organisasi.

Menurut Noe, et. al. (2010:05), manajemen sumber daya manusia mengacu pada kebijakankebijakan, praktik-praktik, serta sistem-sistem yang mempengaruhi perilaku, sikap, dan kinerja karyawan. Sedangkan menurut Gomes (2003:4) berpendapat bahwa manajemen sumber daya manusia adalah pengembangan dan pemanfaatan personil (pegawai) bagi pencapaian yang efektif mengenai sasaran-sasaran dan tujuan individu, organisasi masyarakat, nasional dan internasional. Sedangkan menurut Mondy (2008:4), manajemen sumber daya manusia adalah pemanfaatan sejumlah individu untuk mencapai tujuan organisasi.

Manajemen sumber daya manusia mempunyai arti proses, ilmu, dan seni manajemen yang mengatur tentang sumber daya manusia yang ada dalam organisasi. Dari beberapa pendapat di atas, maka dapat disimpulkan manajemen sumber daya manusia adalah kegiatan yang dilakukan guna mencapai tujuan individu maupun organisasi secara efektif dan efisien agar menghasilkan sumber daya manusia yang produktif dan berkualitas.

\section{Disiplin Kerja}

Di dalam kehidupan sehari-hari, di mana pun manusia berada, dibutuhkan peraturan-peraturan dan ketentuan-ketentuan yang akan mengatur dan membatasi setiap kegiatan dan perilakunya. Menurut Sutrisno (2009:86), disiplin adalah sikap kesediaan dan kerelaan seseorang untuk mematuhi dan menaati norma-norma peraturan yang berlaku di sekitarnya. Menurut Saydam (2000:284), menyebutkan bahwa disiplin adalah pelatihan, khususnya pelatihan pikiran dan sikap untuk menghasilkan pengendalian diri, kebiasaan-kebiasaan untuk menaati peraturan yang berlaku. Sedangkan menurut Rivai (2005:444), mengemukakan bahwa disiplin adalah suatu alat yang digunakan para manajer untuk berkomunikasi dengan karyawan agar mereka bersedia untuk mengubah suatu perilaku serta sebagai upaya untuk mengingatkan kesadaran dan kesediaan seseorang menaati semua peraturan-peraturan yang ada di perusahaan dan norma-norma sosial yang berlaku.

Disiplin bentuk suatu dari pengendalian dalam menaati peraturan untuk mengubah suatu perilaku lewat kesadaran dan kesediaan seseorang. Berdasarkan pendapat-pendapat di atas, penulis menyimpulkan bahwa disiplin adalah peraturanperaturan yang digunakan para manajer untuk berkomunikasi dengan karyawan agar setiap orang menaati norma-norma sosial yang berlaku.

\section{Komunikasi}

Kata komunikasi berasal dari bahasa latin "communis" atau "communicatus" yang memiliki makna "berbagi" atau "menjadi milik bersama" yaitu usaha yang memiliki tujuan untuk kebersamaan atau kesamaan makna.

Menurut Purwanto (2011:4), Komunikasi adalah suatu proses pertukaran informasi antar individu melalui suatu sistem yang biasa (lazim), baik dengan simbol-simbol, sinyal-sinyal maupun perilaku atau tindakan. Menurut Handoko (2009), komunikasi adalah proses pemindahan pengertian dalam bentuk gagasan atau informasi dari seseorang ke orang lain. Sedangkan menurut Dewi (2007:3), komunikasi pada dasarnya dapat dipandang dari berbagai dimensi. Jika dipandang sebagai proses, komunikasi merupakan kegiatan pengiriman dan penerimaan pesan yang berlangsung secara dinamis. Secara simbolik, komunikasi menggunakan berbagai lambang atau simbol yang dinyatakan dalam bentuk nonverbal (isyarat, gerak, dan ekspresi) maupun verbal (bahasa lisan dan tertulis).

Dimanapun kita tinggal dan apapun pekerjaan kita, kita selalu membutuhkan komunikasi dengan orang lain. Manusia tidak bisa hidup sendirian. Ia secara kodrati harus hidup dengan manusia lain, baik demi kelangsungan dan keamanan hidupnya, maupun demi keturunannya. Berdasarkan pendapat para ahli di atas dapat disimpulkan komunikasi adalah proses petukaran informasi antar individu untuk menginterpretasikan suatu yang diinginkan.

\section{Kinerja Pegawai}

Kinerja merupakan salah satu unsur yang tidak dapat dipisahkan dalam suatu organisasi. Menurut Gomes (2003:123), kinerja merupakan suatu kondisi yang harus diketahui dan diinformasikan kepada pihak-pihak tertentu untuk mengetahui tingkat pencapaian hasil suatu instansi dihubungkan dengan visi yang diemban suatu organisasi serta mengetahui dampak negatif dan positif dari suatu kebijakan operasional yang diambil. Menurut Mangkunegara (2013:67), istilah kinerja berasal dari kata job performance atau actual performance (prestasi kerja atau prestasi sesungguhnya yang dicapai oleh seseorang).

Kinerja (prestasi kerja) adalah hasil kerja secara kualitas dan kuantitas yang dicapai oleh seorang pegawai dalam melaksanakan tugasnya sesuai dengan tanggung jawab yang diberikan kepadanya. Sedangkan menurut Mathis dan John (2006:378), kinerja (performance) pada dasarnya adalah apa yang dilakukan atau tidak dilakukan oleh karyawan. Kinerja karyawan yang umum untuk kebanyakan pekerjaan meliputi elemen seperti: kuantitas dan kualitas dari hasil kehadiran dan kemampuan bekerjasama. 
Seorang pegawai yang baik pasti mencerminkan kinerja yang baik. Kinerja sering disebut hasil kerja. Berdasarkan pendapat ahli di atas, kinerja merupakan hasil kerja dan prestasi kerja dalam menyelesaikan tugas atau tanggung jawab seseorang yang diberikan oleh organisasi.

\section{Pengaruh Disiplin Kerja dan Komuniasi \\ Terhadap Kinerja Pegawai}

Kinerja pegawai dalam suatu organisasi atau perusahaan dapat dipengaruhi oleh disiplin kerja dan komunikasi. Kedisiplinan adalah salah satu faktor yang terpenting dalam suatu organisasi. Disiplin dapat mendukung keberhasilan kinerja pada setiap pegawai. Sedangkan komunikasi adalah faktor yang mempengaruhi kinerja pegawai dalam suau organisasi.

Menurut Rivai (2005:444), mengatakan bahwa disiplin pegawai yang tinggi, maka kinerja pegawai akan semakin tinggi pula, dan sebaliknya jika disiplin pegawai menurun, maka kinerja pegawai akan semakin menurun. Sehingga dapat dikatakan bahwa disiplin kerja berpengaruh terhadap kinerja pegawai.

Komunikasi yang baik dalam suatu organisasi akan mampu menunjang kinerja pegawai menjadi lebih baik lagi, dengan kata lain kinerja pegawai pada suatu organisasi dapat dipengaruhi oleh komunikasi. Menurut Purwanto (2006:3), menyatakan bahwa hubungan komunikasi yang baik, dalam arti dapat dipahami dengan jelas antar atasan dan bawahan merupakan salah satu kunci keberhasilan organisasi mencapai tujuan organisasi yang ditetapkan. Suksesnya pelaksanaan tugas pimpinan untuk meningkatkan kinerja itu sebagian besar ditentukan oleh kemahirannya menjalin komunikasi yang tepat dengan semua pihak, secara horizontal, ke atas, ke bawah, dan diagonal.

Dari uraian teori di atas, dapat disimpulkan bahwa semakin baik disiplin kerja dan komunikasi yang diberikan, maka kinerja pegawai semakin tinggi, sebaliknya semakin buruk disiplin kerja dan komunikasi yang diberikan, maka kinerja pegawai akan menurun.

\section{PEMBAHASAN}

\section{Analisis Deskriptif Kualitatif}

Analisis deskriptif kualitatif dimaksudkan untuk mendapatkan gambaran atau deskripsi mengenai pengaruh brand image dan persepsi konsumen terhadap keputusan pembelian konsumen di Indomaret. Sesudah pengujian data, maka langkah selanjutnya peneliti melakukan pengkajian analisis kualitatif sebagai gambaran fenomena dari variabel penelitian pada saat sekarang ini. Setelah kuesioner diolah, maka nilai-nilai jawaban dari setiap data responden dibagai menjadi beberapa kelas interval.

Adapun penetapan kriteria nilai rata-rata jawaban dari responden tersebut dimasukkan kedalam kelas-kelas interval dengan penentuan intervalnya memakai rumus sebagai berikut:
Interval Kelas $=$ Nilai Tertinggi-Nilai Terendah

...... (Sugiyono, 2013:172)

$$
\text { Interval Kelas }=\frac{5-1}{5}=\frac{4}{5}=0,8
$$

Kriteria:

Nilai Tertinggi adalah $=5$

Nilai terendah adalah $=1$

Jumlah Kelas adalah $=5$

Dari rumus di atas dapat diperoleh interval kelas 0,8 sehingga berlaku ketentuan mengenai jawaban reponden dengan hasil sebagai berikut:

\begin{tabular}{|c|c|c|c|}
\hline \multirow{2}{*}{$\begin{array}{c}\text { Nilai Intel } \\
\text { Nilai } \\
\text { Interval }\end{array}$} & \multicolumn{3}{|c|}{ Kategori } \\
\hline & $\begin{array}{l}\text { Brand } \\
\text { Image }\end{array}$ & $\begin{array}{c}\text { Persepsi } \\
\text { Konsumen }\end{array}$ & $\begin{array}{l}\text { Keputusan } \\
\text { Pembelian }\end{array}$ \\
\hline $\begin{array}{l}1,00 \\
1,80\end{array}$ & $\begin{array}{l}\text { Sangat } \\
\text { Tidak } \\
\text { Baik } \\
\text { (STS) }\end{array}$ & $\begin{array}{l}\text { Sangat } \\
\text { Tidak Baik } \\
\text { (STS) }\end{array}$ & $\begin{array}{l}\text { Sangat } \\
\text { Tidak Baik } \\
\text { (STS) }\end{array}$ \\
\hline $\begin{array}{l}1,81 \\
2,60\end{array}$ & $\begin{array}{l}\text { Tidak } \\
\text { Baik } \\
\text { (TS) }\end{array}$ & $\begin{array}{l}\text { Tidak Baik } \\
\text { (TS) }\end{array}$ & $\begin{array}{l}\text { Tidak Baik } \\
\text { (TS) }\end{array}$ \\
\hline $\begin{array}{l}2,61 \\
3,40\end{array}$ & $\begin{array}{l}\text { Kurang } \\
\text { Baik } \\
(\mathrm{KS})\end{array}$ & $\begin{array}{l}\text { Kurang } \\
\text { Baik } \\
\text { (KS) }\end{array}$ & $\begin{array}{l}\text { Kurang } \\
\text { Baik } \\
(\mathrm{KS})\end{array}$ \\
\hline $\begin{array}{l}3,41 \\
4,20\end{array}$ & $\begin{array}{l}\text { Baik } \\
(\mathrm{S})\end{array}$ & $\begin{array}{l}\text { Baik } \\
(\mathrm{S})\end{array}$ & $\begin{array}{l}\text { Baik } \\
(\mathrm{S})\end{array}$ \\
\hline $\begin{array}{ll}4,21 \quad- \\
5,00\end{array}$ & $\begin{array}{l}\text { Sangat } \\
\text { Baik } \\
(\mathrm{SS})\end{array}$ & $\begin{array}{l}\text { Sangat Baik } \\
(\mathrm{SS})\end{array}$ & $\begin{array}{l}\text { Sangat Baik } \\
(\mathrm{SS})\end{array}$ \\
\hline
\end{tabular}

Sumber: hasil pengolahan data kuesioner(2017)

a. Gambaran Disiplin Kerja Pada Badan Pertahanan Kantor Kota Pematangsiantar

Dapat dilihat bahwa dimensi menjalankan kewajiban dengan indikator mengucapkan sumpah PNS berada pada rata-rata 3,81 dengan kriteria jawaban baik disebabkan adanya kesadaran pegawai dalam mengucapkan sumpah saat menjadi PNS sehingga pegawai bersungguh-sungguh dalam mengucapkannya. Indikator mengucapkan sumpah jabatan berada pada rata-rata 4,06 dengan kriteria baik. Hal ini disebabkan adanya kesadaran pegawai mengenai sumpah jabatan sehingga membuat pegawai tidak memanfaatkan jabatannya untuk halhal negatif. Indikator setia terhadap Pancasila berada pada rata-rata 4,10 dengan kriteria sangat baik. Hal ini disebabkan Pancasila merupakan dasar dari Negara Republik Indonesia sehingga pegawai menerapkan nilai-nilai Pancasila dalam bekerja dan dalam kehidupan sehari-hari.

Indikator setia terhadap Negara berada pada rata-rata 4,16 dengan kriteria baik. Hal ini disebabkan pegawai sebagai warga negara Indonesia memiliki rasa nasionalisme terhadap negara sendiri. Indikator menaati peraturan perundang-undangan berada pada rata-rata 3,81 dengan kriteria baik yang dikarenakan pegawai telah menaati aturan-aturan di dalam undang-undang dalam melaksanakan pekerjaan. Indikator melaksanakan tugas kedinasan berada pada rata-rata 3,90 dengan kriteria baik. Hal ini dikarenakan adanya keinginan pegawai untuk 
melaksanakan tugas dengan baik sehingga tujuan organisasi bisa tercapai.

Indikator menjunjung tinggi kehormatan negara berada pada rata-rata 4,03 dengan kriteria baik yang disebabkan adanya kesadaran pegawai untuk menjaga sikap sebagai pegawai negeri sipil yang menjaga nama baik Negara. Indikator mengutamakan kepentingan negara berada pada ratarata 4,16 dengan kriteria baik, dikarenakan sebagai pegawai negeri sipil ditetapkan untuk bekerja di negara sendiri dari pada di negara lain. Indikator memegang rahasia jabatan pada rata-rata 4,10 dengan kriteria baik yang dikarenakan para pegawai dapat memegang rahasia pekerjaan yang telah diberikan kepadanya.

Indikator bekerja dengan jujur berada pada ratarata 4,06 dengan kriteria baik yang disebabkan pegawai memiliki kemauan untuk bekerja dengan jujur dan tidak ada yang ditutupi dalam melakukan hal apapun. Indikator melaporkan jika mengetahui apabila ada hal yang membahayakan negara berada pada rata-rata 3,81 dengan kriteria baik, karena setiap ada masalah yang dapat membahayakan negara maka pegawai langsung melaporkan kepada yang berwajib. Indikator menaati ketentuan jam kerja berada pada rata-rata 3,39 dengan kriteria cukup baik, hal ini dikarenakan kurangnya pegawai dalam menaati ketentuan jam kerja seperti pegawai sering tidak masuk kerja tanpa alasan yang sah.

Indikator mencapai sasaran kerja pegawai berada pada rata-rata 4,06 dengan kriteria baik Pegawai dapat mencapai sasaran kerja karena adanya rencana kerja dan target yang akan dicapai oleh pegawai. Indikator memelihara barang-barang milik negara berada pada rata-rata 4,03 dengan kriteria baik, hal ini disebabkan adanya kesadaran pegawai untuk menjaga barang-barang milik negara yang diberikan padanya dengan optimal. Indikator memberikan pelayanan yang baik pada masyarakat memiliki rata-rata 3,39 dengan kriteria cukup baik dikarenakan kurangnya kesadaran pegawai dalam memberikan pelayanan kepada masyarakat.

Indikator membimbing bawahan melaksanakan tugas memiliki rata-rata 4,10 dengan kriteria baik. Hal ini disebabkan sudah terjalinnya komunikasi yang baik antara pegawai senior dengan pegawai junior dalam melaksanakan pekerjaan. Indikator memberikan kesempatan pada bawahan untuk mengembangkan karir bernilai rata-rata 3,81 dengan kriteria baik. Hal ini dikarenakan atasan memberikan kesempatan kepada bawahan untuk mengembangkan karir dengan memberikan pelatihan. Indikator menaati peraturan kedinasan memiliki rata-rata 3,39 dengan kriteria cukup baik. Hal ini dikarenakan pimpinan kurang tegas kepada pegawai yang tidak menaati aturan sehingga ada beberapa pegawai yang melanggar aturan tersebut.

Dimensi menjauhi larangan untuk indikator menyalahgunakan wewenang berada pada rata-rata 3,90 dengan kriteria baik. Hal ini disebabkan pegawai sadar untuk tidak menyalahgunakan wewenang yang telah diberikan kepadanya. Indikator menjadi perantara untuk mendapatkan keuntungan pribadi berada pada rata-rata 4,23 dengan kriteria sangat baik, dikarenakan pegawai tidak akan menggunakan kewenangan orang lain demi mendapatkan keuntungan pribadi. Indikator tanpa izin bekerja untuk negara lain berada pada rata-rata 4,10 dengan kriteria baik. Hal ini disebabkan tidak adanya pegawai yang bekerja untuk negara lain.

Indikator bekerja pada perusahaan asing berada pada rata-rata 4,06 dengan kriteria baik, disebabkan tidak adanya pegawai yang bekerja pada perusahaan asing. Indikator memiliki barang-barang milik negara secara tidak sah berada pada rata-rata 4,23 dengan kriteria sangat baik. Hal ini disebabkan pegawai telah mengetahui bahwa barang-barang milik negara yang diberikan berupa fasilitas dan hanya boleh dipergunakan untuk urusan pekerjaan. Indikator melakukan kegiatan bersama dengan atasan untuk kepentingan pribadi berada pada ratarata 3,74 dengan kriteria baik. Hal ini disebabkan pimpinan selalu tegas kepada pegawai untuk tidak melakukan kegiatan bersama, di dalam maupun di luar lingkungan kerjanya dengan tujuan keuntungan pribadi.

Indikator memberikan hadiah pada seseorang untuk diangkat dalam jabatan berada pada rata-rata 4,03 dengan kriteria baik, dapat diketahui pegawai tidak pernah memberi hadiah kepada siapapun baik secara langsung atau tidak langsung dengan dalih apapun untuk diangkat dalam jabatan. Indikator menerima hadiah yang berhubungan dengan jabatan berada pada rata-rata 3,81 dengan kriteria baik, karena pegawai selalu menolak hadiah atau suatu pemberian apa saja dari siapapun juga yang berhubungan dengan jabatan atau pekerjaannya. Indikator bertindak sewenang-wenang terhadap bawahan berada pada rata-rata 4,23 dengan kriteria sangat baik. Hal ini dikarenakan atasan selalu memperlakukan bawahan dengan baik dan tidak bertindak sewenang-wenang terhadap bawahan.

Indikator melakukan dengan tindakan yang mempersulit pihak yang dilayani berada pada ratarata 3,74 dengan krieteia baik. Hal ini dikarenakan pegawai tidak melakukan suatu tindakan yang dapat menghalangi atau mempersulit salah satu pihak yang dilayani sehingga mengakibatkan kerugian bagi yang dilayani. Indikator menghalangi berjalannya tugas kedinasan berada pada rata-rata 4,16 dengan kriteria baik. Hal ini disebabkan tidak adanya pegawai menghalangi berjalannya tugas kedinasan yang dapat merugikan organisasi tersebut. Indikator menjadi peserta kampanye dengan menggunakan fasilitas negara berada pada rata-rata 4,06 dengan kriteria baik. Hal ini disebabkan adanya kesadaran pegawai bahwa pegawai negeri sipil (PNS) harus bersikap netral dalam pemilihan umum.

Indikator mendukung calon peserta pemilu dengan menggunakan fasilitas negara berada pada rata-rata 4,03 dengan kriteria baik. Hal ini disebabkan adanya kesadaran pegawai untuk menggunakan fasilitas yang diberikan negara hanya ketika pegawai menjalankan tugas kedinasan yang telah dipercayakan padanya. Indikator membuat keputusan yang menguntungkan salah satu calon 
peserta pemilu berada pada rata-rata 4,23 dengan kriteria sangat baik, disebabkan pegawai membuat keputusan untuk tidak melakukan tindakan yang menguntungkan atau merugikan salah satu pasangan calon peserta pemilu.

Secara keseluruhan disiplin kerja pegawai memiliki nilai rata-rata 3,96 dengan kriteria baik Nilai rata-rata disiplin kerja tertinggi sebesar 4,23 dengan kriteria sangat baik berada pada dimensi menjauhi larangan, untuk indikator memiliki barangbarang milik negara secara tidak sah, bertindak sewenang-wenang terhadap bawahan dan membuat keputusan yang menguntungkan salah satu calon peserta pemilu. Nilai rata-rata disiplin kerja terendah sebesar 3,39 dengan kriteria baik berada pada dimensi menjalankan kewajiban, untuk indikator menaati ketentuan jam kerja, memberikan pelayanan yang baik kepada masyarakat dan menaati peraturan kedinasan.

\section{b. Gambaran Komunikasi pada Badan Pertahanan Nasional Kantor Pematangsiantar}

Untuk dimensi komunikasi ke bawah pada indikator memberikan informasi berada pada ratarata 3,74 dengan kriteria baik. Hal ini disebabkan informasi yang diberikan atasan kepada bawahan dapat dimengerti dengan baik. Indikator memberikan intruksi berada pada rata-rata 3,90 dengan kriteria baik. Hal ini disebabkan pimpinan rutin dalam memberikan instruksi kegiatan kerja yang disampaikan pada saat apel pagi yang diadakan setiap hari. Indikator memberikan arahan berada pada rata-rata 3,77 dengan kriteria baik. Hal ini disebabkan dalam setiap penyelesaian tugas atasan selalu memberikan arahan yang baik kepada bawahannya. Indikator mengkomunikasikan hasil kinerja berada pada rata-rata 3,74 dengan kriteria baik. Hal ini disebabkan pimpinan melakukan komunikasi langsung kepada pegawai dalam menyampaikan hasil kerja yang telah dicapai pegawai.

Pada dimensi komunikasi ke atas dengan indikator menyampaikan gagasan berada pada ratarata 4,19 dengan kriteria baik. Hal ini disebabkan karena pegawai mampu memberikan ide pokok/ gagasan kepada pimpinan pada saat ada pertemuan rapat maupun dalam pelaksanaan tugas di lapangan. Indikator menginformasikan laporan kinerja berada pada rata-rata 4,19 dengan kriteria baik. Hal ini disebabkan pegawai selalu memberitahukan laporan dari hasil kinerja yang dicapai kepada pimpinan secara langsung. Indikator menyampaikan keluhan pekerjaan berada pada rata-rata 3,90 dengan kriteria baik. Hal ini disebabkan pegawai tidak pernah menutupi setiap masalah yang ditemukan dalam pekerjaan dan sesegera mungkin melakukan perundingan dengan pimpinan.

Pada dimensi komunikasi horizontal dengan indikator memecahkan masalah berada pada rata-rata 3,81 dengan kriteria baik, karena pegawai telah dibekali kemampuan dalam memecahkan setiap masalah yang berhubungan dengan pekerjaan dengan cara melakukan perundingan dengan sesama rekan kerja. Indikator kerja sama berada pada rata-rata 4,19 dengan kriteria baik. Hal ini dikarenakan pegawai mampu bekerja sama dengan rekan kerjanya dengan baik. Indikator menyampaikan informasi pada ratarata 4,06 dengan kriteria baik. Hal ini disebabkan pegawai selalu melakukan komunikasi yang baik dengan sesama rekan kerja agar tidak terjadi kesalahan-kesalahan yang fatal dalam menyampaikan informasi.

Pada dimensi komunikasi diagonal dengan indikator kejelasan informasi berada pada rata-rata 4,16 dengan kriteria baik. Hal ini disebabkan walaupun tidak berada dalam satu tim tetapi informasi yang diberikan selalu jelas dan tepat. Indikator memperluas informasi berada pada ratarata 3,90 dengan kriteria baik. Hal ini disebabkan informasi yang penting terkait pekerjaan diperluas ke rekan kerja yang bukan satu tim dengan cepat. Pada indikator membina hubungan berada pada rata-rata 4,10 dengan kriteria baik. Disebabkan adanya keharmonisan antara sesama rekan yang bukan satu tim untuk bekerja sama yang baik sehingga hubungan rekan kerja yang bukan satu tim menjadi baik.

Secara keseluruhan dapat dilihat bahwa nilai rata-rata komunikasi pada Badan Pertanahan Nasional Kantor Kota Pematangsiantar berada pada nilai rata-rata 3,98 dengan kriteria baik. Kemudian nilai rata-rata tertinggi sebesar 4,19 dengan kriteria baik berada pada dimensi komunikasi ke atas, untuk indikator menyampaikan gagasan, menginformasikan laporan kinerja, dan pada dimensi komunikasi horizontal untuk indikator kerjasama. Sedangkan nilai rata-rata terendah sebesar 3,74 dengan kriteria baik berada pada dimensi komunikasi ke bawah, untuk indikator memberikan informasi dan mengkomunikasikan hasil kinerja.

\section{c. Gambaran Kinerja Pegawai pada Badan Pertahanan Nasional Kantor Kota \\ Pematangsiantar}

Dapat dilihat bahwa dimensi Sasaran Kinerja Pegawai (SKP) dengan indikator pertanggungjawaban hasil kerja berada pada rata-rata 4,32 dengan kriteria sangat baik. Hal ini disebabkan setiap pegawai melakukan tugas dan menulis laporannya sendiri sebagai pertanggungjawaban langsung kepada pimpinan. Indikator pencapaian target kerja berada pada rata-rata 4,16 dengan kriteria baik. Hal ini dikarenakan pegawai mampu mencapai target kerjanya dengan baik. Indikator tingkat penyelesaian pekerjaan berada pada rata-rata 4,16 dengan kriteria baik. Hal ini disebabkan pegawai mampu menyelesaikan tugasnya dengan tepat waktu.

Indikator tingkat mutu hasil kerja berada pada rata-rata 4,32 dengan kriteria baik. Dikarenakan pegawai mampu mengerjakan tugasnya dengan hasil yang baik dan tepat waktu. Indikator ketelitian dalam bekerja berada pada rata-rata 4,16 dengan kriteria baik. Hal ini disebabkan pegawai selalu berhati-hati dalam melakukan pekerjaannya agar tidak 
menimbulkan permasalahan bagi organisasi. Indikator kerapian dalm bekerja berada pada ratarata 4,16 dengan kriteria baik, karena pegawai melakukan pekerjaannya dengan sungguh-sungguh dan fokus.

Indikator efisiensi waktu dalam pekerjaan berada pada rata-rata 4,32 dengan kriteria baik. Hal ini disebabkan pegawai selalu menghargai waktu dalam bekerja. Indikator menyelesaikan pekerjaan dengan tepat waktu berada pada rata-rata 3,81 dengan kriteria baik. Hal ini dikarenakan pegawai tetap fokus dalam menyelesaikan pekerjaannya dan tidak bermalas-malasan pada saat bekerja. Indikator tingkat kehadiran berada pada rata-rata 3,74 dengan kriteria baik. Hal ini disebabkan sebagian besar pegawai mampu hadir pada jam kerja yang telah ditentukan.

Indikator anggaran yang dibutuhkan berada pada rata-rata 3,81 dengan kriteria baik. Hal ini disebabkan perusahaan telah memberikan anggaran yang sesuai untuk pekerjaan yang diperintahkan kepada pegawai. Indikator biaya yang digunakan berada pada rata-rata 4,16 dengan kriteria baik. Hal ini disebabkan pegawai telah menggunakan biaya sesuai dengan anggaran yang ditetapkan untuk keperluan pekerjaan mereka. Indikator dalam mengalokasikan biaya berada pada rata-rata 4,32 dengan kriteria sangat baik. Hal ini disebabkan pegawai dapat memanfaatkan anggaran yang diberikan dengan baik.

Pada dimensi Perilaku Kerja (PK) dengan indikator tingkat pelayanan berada pada rata-rata 4,19 dengan kriteria baik. Hal ini dikarenakan pegawai negeri sipil (PNS) harus memberikan pelayanan sebaik-baiknya kepada masyarakat berdasarkan peraturan pemerintah. Indikator sikap dan perilaku memberikan pelayanan berada pada rata-rata 4,06 dengan kriteria baik. Hal ini disebabkan pegawai selalu berusaha memberikan pelayanan yang terbaik kepada masyarakat. Indikator kecepatan pelayanan berada pada rata-rata 4,10 dengan kriteria baik. Hal ini dikarenakan pegawai selalu cepat dalam memberikan pelayanan kepada masyarakat sehingga masyarakat tidak kecewa. Indikator tingkat kejujuran pegawai berada pada rata-rata 4,23 dengan kriteria sangat baik, karena pegawai bersikap jujur dalam bekerja ketika didalam kantor dan diluar kantor seperti dilapangan.

Indikator tingkat keberanian dalam pengambilan resiko berada pada rata-rata 4,19 dengan kriteria baik. Hal ini dikarenakan pegawai mampu dan berani mengambil resiko yang ada dalam pekerjaan. Indikator tanggung jawab dalam suatu pekerjaan berada pada rata-rata 4,16 dengan kriteria baik. Hal ini disebabkan pegawai memiliki rasa bertanggung jawab atas kesalahan yang dibuatnya pada saat bekerja. Indikator pencapaian dalam menyelesaikan pekerjaan berada pada rata-rata 4,23 dengan kriteria baik. Hal ini disebabkan pegawai mampu menyelesaikan pekerjaan yang diberikan pimpinan dengan tepat waktu.

Indikator efesiensi waktu dalam menyelesaikan suatu pekerjaan berada pada rata-rata 3,90 dengan kriteria baik. Hal ini disebabkan pegawai mampu menghargai waktu dalam pekerjaannya. Indikator tingkat kesediaan melakukan pekerjaan tanpa diperintah berada pada rata-rata 4,10 dengan kriteria baik. Hal ini disebabkan pegawai mampu menyelesaikan tugasnya dengan baik tanpa diperintah oleh atasan. Indikator tingkat kehadiran berada pada rata-rata 4,19 dengan kriteria baik. hal ini dikarenakan pegawai selalu hadir dalam bekerja dan mampu menaati ketentuan jam kerja Pegawai Negeri Sipil (PNS).

Indikator tingkat sistem jam kerja berada pada rata-rata 3,39 dengan kriteria cukup baik. Hal ini disebabkan pegawai yang sering telat hadir ketika apel pagi pada jam 07.30 WIB dan pada apel sore pegawai sering malas untuk menghadiri pada jam 16,30 WIB. Indikator respon kepatuhan terhadap aturan berada pada rata-rata 4,19 dengan kriteria baik. Hal ini dikarenakan pimpinan tegas dalam memberikan sanksi untuk pegawai yang menyalahi aturan. Indikator kerja sama pegawai berada pada rata-rata 4,23 dengan kriteria sangat baik. Hal ini disebabkan pegawai mampu bekerja sama dengan pegawai yang setara, lebih rendah, ataupun lebih tinggi darinya.

Indikator saling memberi ide-ide antar pegawai atas tugas yang dibebankan berada pada rata-rata 4,19 dengan kriteria baik, karena pegawai selalu saling tukar pikiran untuk menyelesaikan suatu pekerjaan. Indikator saling berkomunikasi yang baik terhadap sesama pegawai demi kelancaran pekerjaan berada pada rata-rata 4,06 dengan kriteria baik. Hal ini disebabkan pegawai mampu melakukan komunikasi yang baik demi kelancaran suatu pekerjaan. Indikator pimpinan dalam menempatkan posisi pegawai berada pada rata-rata 4,29 dengan kriteria sangat baik, karena pimpinan menempatkan posisi pegawai sesuai bidangnya masing-masing.

Indikator kemampuan memimpin berada pada rata-rata 4,19 dengan kriteria baik. Hal ini disebabkan pimpinan mampu memimpin suatu organisasi sehingga organisasi tersebut semakin lebih baik. Indikator kemampuan dalam bekerja sama dengan rekan kerja berada pada rata-rata 4,29 dengan kriteria sangat baik. Hal ini dikarenakan adanya kesadaran pegawai bahwa apabila suatu pekerjaan dilakukan bersama-sama akan lebih baik.

Secara keseluruhan dapat dilihat bahwa nilai ratarata untuk variabel kinerja pegawai berdasarkan jawaban responden adalah 4,12 dengan kriteria jawaban baik. Nilai rata-rata tertinggi adalah sebesar 4,32 dengan kriteria jawaban sangat baik diperoleh dimensi sasaran kinerja pegawai (SKP) pada indikator pertanggungjawaban hasil kerja, tingkat mutu hasil kerja, efisiensi waktu Efisiensi waktu dalam pekerjaan dan mengalokasikan biaya. Sedangkan nilai rata-rata terendah adalah 3,39 pada dimensi perilaku kerja (PK) pada indikator tingkat sistem jam. 


\section{Deskriptif Kuantitatif}

\section{a. Regresi Linear Berganda}

Regresi berganda digunakan peneliti dengan maksud untuk mengetahui ada atau tidaknya pengaruh disiplin kerja dan komunikasi terhadap kinerja pegawai di Badan Pertanahan Indonesia Kota Pematangsiantar.

. Persamaan yang menyatakan bentuk hubungan antara variabel independent $(\mathrm{X})$ variabel dependent (Y) disebut dengan persamaan regresi.

Adapun persamaan regresi berganda yang dipergunakan adalah sebagai berikut:

Adapun persamaan regresi berganda yang dipergunakan adalah sebagai berikut:

$$
\hat{\mathrm{Y}}=\mathrm{b}_{0}+\mathrm{b}_{1} \mathrm{X}_{1}+\mathrm{b}_{2} \mathrm{X}_{2}
$$

(Simbolon, 2009:239)

Keterangan :

$\begin{array}{ll}\hat{\mathrm{Y}} & =\text { Variabel Terikat (Keputusan } \\ \text { Pembelian) } & \\ \mathrm{b}_{0} & \text { Konstanta } \\ \mathrm{b}_{1}, \mathrm{~b}_{2} & = \\ \mathrm{X}_{1} & \text { Koefisien Arah Regresi } \\ \mathrm{X}_{2} & \text { Variabel Bebas 1 (Disiplin Kerja) } \\ & \text { Variabel Bebas 2 (Komunikasi) }\end{array}$

Berdasarkan hasil pengolahan data didapat persamaan regresi linier sederhana yaitu:

$\hat{\mathrm{Y}}=34,319+0,445 \mathrm{X}_{1}+0,638 \mathrm{X}_{2}$, Artinya terdapat pengaruh yang positif antara disiplin kerja $\left(\mathrm{X}_{1}\right)$ dan komunikasi $\left(\mathrm{X}_{2}\right)$ terhadap kinerja pegawai $(\mathrm{Y})$ di PT Badan Pertahanan Indonesia Kota Pematangsiantar.

\section{b. Koefisen Korelasi dan Determinasi}

Analisis distribusi frekuensi jawaban responden menurut skor dari variabel $\mathrm{X}_{1}$ (disiplin kerja), $\mathrm{X}_{2}$ (komunikasi) dan $\mathrm{Y}$ (kinerja pegawai) dimaksud sebagaimana telah dilakukan, hanyalah bermanfaat untuk memberikan informasi pendahuluan mengenai pola distribusi jawaban responden menurut skor. Selanjutnya, dilakukan perhitungan korelasi berupa derajat atau kedalaman hubungan fungsional yang menjelaskan hubungan antar perubah, dinyatakan dengan yang dinamakan koefisien korelasi yang sering disimbolkan dengan $r$. Nilai $r$ dapat dihitung menggunakan SPSS Versi 21.

Nilai $r=0,826$, yang artinya terdapat hubungan yang sangat kuat dan positif antara disiplin kerja, komunikasi dengan kinerja pegawai di PT Badan Pertahanan Indonesia Kota Pematangsiantar.

Kemudian diperoleh nilai koefisien determinasi $\mathrm{R}$ Square $=0,682$, artinya tinggi kinerja pegawai di PT Badan Pertahanan Indonesia Kota Pematangsiantar sebesar $68,2 \%$ dapat dijelaskan oleh disiplin kerja dan komunikasi sedangkan sisanya 21,8\% dipengaruhi oleh faktor lain seperti, kompensasi, lingkungan kerja, budaya organsasi, motivasi, etos kerja dan lain-lain.

\section{c. Uji Hipotesis}

\section{1) Uji Simultan (Uji F)}

Uji F digunakan untuk mengetahui apakah varabel bebas (peran kepemimpinan dan kerjasama tim) berpengaruh terhadap variabel terikat (kinerja pegawai) secara bersama-sama atau simultan Pengujian ini dilakukan jika $F_{\text {hitung }}>F_{\text {tabel }}$ atau signifikansi $\leq 0,05$ maka $\mathrm{H}_{0}$ ditolak, artinya disiplin kerja dan komunikasi berpengaruh positif dan signifikan terhadap kinerja pegawai di Badan Pertanahan Indonesia Kota Pematangsiantar.

Diperoleh nilai $F_{\text {hitung }}$ sebesar 29,958 sedangkan $F_{\text {tabel }}$ dengan $(0,05 ; 2$ vs 31$)$ sebesar 3,34 , atau dengan signifikan $0,000<\alpha 0,05$, maka $\mathrm{H}_{0}$ ditolak, artinya disiplin kerja dan komunikasi berpengaruh positip dan signifikan terhadap kinerja pegawai di Badan Pertanahan Indonesia Kota Pematangsiantar.

\section{Uji Parsial (Uji t)}

Uji $\mathrm{t}$ digunakan untuk menguji variabel bebas terhadap variabel terikat secara parsial. Untuk menguji hasil perhitungan regresi dapat dilakukan pengujian hipotesis untuk mengetahui apakah variabel bebas mempunyai pengaruh atau tidak terhadap variabel terikat secara parsial.

Diperoleh nilai $t_{\text {hitung }}$ pada variabel $\mathrm{X}_{1}$ (disiplin kerja) sebesar 3,443 > dari $t_{\text {tabel }}$ dengan $\mathrm{df}=\mathrm{n}-\mathrm{k}-1$ (31-2$1=28$ ) sebesar 2,048 atau taraf signifikan 0,002 $<\alpha$ 0,05 maka $\mathrm{H}_{0}$ ditolak, artinya disiplin kerja berpengaruh positif dan signifikan terhadap kinerja pegawai di Badan Pertanahan Indonesia Kota Pematangsiantar. Kemudian nilai $t_{\text {hitung }}$ pada variabel $\mathrm{X}_{2}$ (persepsi konsumen) sebesar 2,445> dari $\mathrm{t}_{\text {tabel }}$ dengan $\mathrm{df}=\mathrm{n}-\mathrm{k}-1,(31-2-1=28)$ sebesar 2,048 atau taraf signifikan $0,021<\alpha 0,05$, maka $\mathrm{H}_{0}$ ditolak, artinya komunikasi berpengaruh positif dan signifikan terhadap kinerja pegawai di Badan Pertanahan Indonesia Kota Pematangsiantar.

\section{Evaluasi}

a. Disiplin Kerja pada Badan Pertanahan Nasional Kantor Kota Pematangsiantar

Disiplin kerja merupakan salah satu aspek yang harus dimiliki setiap pegawai. Penerapan disiplin pegawai di suatu organisasi akan menciptakan keteraturan dalam bekerja serta tertib dalam segala hal. Pada pegawai Kantor Badan Pertanahan Nasional (BPN) Kota Pematangsiantar harus menerapkan disiplin pada diri sendiri, adanya disiplin untuk mengubah suatu perilaku lewat kesadaran dan kesediaan seseorang.

Dari rekapitulasi jawaban responden mengenai disiplin kerja pada Kantor Badan Pertanahan Nasional (BPN) Kota Pematangsiantar sudah baik, namun masih ada beberapa indikator yang berada dibawah nilai rata-rata. Pada indikator mengucapkan sumpah saat menjadi PNS diperoleh nilai 3,81 dengan kriteria baik, cara meningkatkannya pegawai harus lebih bersungguh-sungguh lagi dalam mengucapkan sumpah pada saat mau menjadi PNS. Indikator selanjutnya adalah menaati peraturan perundang-undangan diperoleh nilai 3,81 dengan kriteria baik, Untuk lebih meningkatkan dalam menaati peraturan perundang-undangan pegawai harus lebih memahami lagi aturan yang mengatur setiap tindakan dalam melaksanakan pekerjaan.

Indikator melaksanakan tugas kedinasan diperoleh nilai 3,90 dengan kriteria baik, cara meningkatkannya pimpinan harus memperhatikan pegawai pada saat melaksanakan tugas kedinasan. Pada indikator melaporkan jika mengetahui apabila ada hal yang membahayakan negara diperoleh nilai 3,81 dengan kriteria baik, Hal yang dapat dilakukan 
untuk meningkatkan indikator ini adalah pegawai harus lebih berani lagi dalam melaporkan hal-hal yang dapat membahayakan negara. Selanjutnya indikator menaati ketentuan jam kerja diperoleh nilai 3,39 dengan kriteria cukup baik, cara mengatasinya pimpinan harus lebih tegas kepada pegawai yang tidak menaati ketentuan jam kerja.

Indikator memberikan pelayanan yang baik kepada masyarakat diperoleh nilai 3,39 dengan kriteria cukup baik, cara mengatasinya pimpinan harus memberikan arahan kepada pegawai dalam memberikan pelayanan yang baik pada masyarakat. Indikator memberikan kesempatan pada bawahan untuk mengembangkan karir diperoleh nilai 3,81 dengan kriteria baik. Hal yang dapat dilakukan untuk mengembangkan karir adalah dengan cara pegawai harus lebih giat lagi dalam bekerja.

Selanjutnya indikator menaati peraturan kedinasan diperoleh nilai 3,39 dengan kriteria cukup baik. Cara mengatasinya pemimpin harus lebih tegas dalam meberikan teguran dan hukaman bagi yang tidak menaati peraturan kedinasan. Pada dimensi menjauhi larangan untuk indikator menyalahgunakan wewenang diperoleh nilai 3,90 dengan kriteria baik. Cara mengatasinya paimpinan harus memberikan sanksi kepada pegawai yang menyalahgunakan wewenang.

Indikator melakukan kegiatan bersama dengan atasan untuk kepentingan pribadi diperoleh nilai 3,74 dengan kriteria baik. Perlunya kesadaran pada diri sendiri untuk tidak melakukan kegiatan dengan atasan demi kepentingan pribadi. Indikator menerima hadiah yang berhubungan dengan jabatan diperoleh nilai 3,81 dengan kriteria baik. Untuk lebih mengatasinya pimpinan harus memberi sanksi kepada pegawai yang menerima hadiah tersebut.

Indikator melakukan tindakan yang dapat mempersulit pihak yang dilayani diperoleh nilai 3,74 dengan kriteria baik. cara mengatasinya pimpinan harus member teguran kepada pegawai yang mempersulit pihak yang dilayani. Dalam hal ini dapat dilihat bahwa disiplin kerja pada Kantor Badan Pertanahan Nasional Kota Pematangsiantar sudah dikategorikan baik. Walaupun sudah dikategorikan baik, para pegawai dan pimpinan harus menjauhi larangan dan menjalankan kewajiban yang telah ditentuan oleh peraturan yang ada.

\section{b. Komunikasi Pada Badan Pertanahan Nasional Kantor Kota Pematangsiantar}

Pada Kantor Badan Pertanahan Nasional (BPN) Kota Pematangsiantar mengoptimalkan komunikasi sebagai upaya menghasilkan kinerja pegawai yang optimal bertujuan untuk memberikan informasi yang tepat, terciptanya keharmonisan sesama pegawai dan agar pegawai mampu bekerjasama dengan baik. Dalam suatu organisasi komunikasi adalah suatu hala yang sangat penting demi terciptanya kesepahaman informasi yang disampaikan. Begitu pula dengan Kantor Badan Pertanahan Nasional (BPN) Kota Pematangsiantar.

Dari rekapitulasi jawaban responden mengenai komunikasi pada Kantor Badan Pertanahan Nasional
(BPN) Kota Pematangsiantar sudah baik, namun masih ada beberapa indikator yang berada pada dibawah nilai rata-rata. Pada indikator memberikan informasi diperoleh nilai 3,74 dengan kriteria baik. Untuk lebih meningkatkannya pimpinan harus menyampaikan informasi yang tepat pada pegawai sehingga pegawai dengan mudah memahami apa yang disampaikan. Indikator mengkomunikasikan hasil kinerja diperoleh nilai 3,74 dengan kriteria baik. Cara meningkatkannya pimpinan harus sering melakukan komunikasi langsung kepada pegawai dalam menyampaikan hasil kerja yang dicapai pegawai.

Selanjutnya pada indikator memecahkan masalah diperoleh nilai 3,81 dengan kriteria baik. Dalam hal ini komunikasi antar pegawai sudah baik terlihat dari mereka saling membantu antar pegawai dalam menyelesaikan suatu masalah pekerjaan, namun pegawai perlu lebih meningkatkan keakraban agar tercipta suasana kerja yang nyaman sehingga komunikasi dapat berjalan lancar. Dalam hal ini dapat dilihat bahwa komunikasi pegawai pada Kantor Kementerian Agama Kota Pematangsiantar sudah dikategorikan baik. Walaupun sudah dikategorikan baik, para pegawai dan pimpinan harus menjaga komunikasi dengan baik demi terciptanya kesepahaman informasi yang disampaikan.

\section{c. Keputusan Pembelian Konsumen di PT Indomarco Prismatama (Indomaret)}

Kinerja merupakan hasil kerja dan prestasi kerja dalam menyelesaikan tugas atau tanggung jawab seseorang yang diberikan oleh organisasi. Hasil tersebut dapat berupa hasil yang baik maupun buruk. Kinerja pegawai pada Kantor Badan Pertanahan Nasional (BPN) Kota Pematangsiantar didasarkan pada dimensi Sasaran Kinerja Pegawai (SKP) dan Perilaku Keja (PK). Dari rekapitulasi jawaban responden mengenai kinerja pegawai pada Kantor Badan Pertanahan Nasional (BPN) Kota Pematangsiantar dapat dinilai baik, hal ini dibuktikan dengan nilai 4,12 yang berkriteria baik.

Dalam mpenelitian kinerja pegawai dari dimensi Sasaran Kinerja Pegawai (SKP) dengan indikator menyelesaikan pekerjaan dengan tepat waktu diperoleh nilai 3,81 dengan kriteria baik. cara mengatasinya dapat dilakukan untuk menyelesaikan pekerjaan dengan tepat waktu adalah dengan memberikan teguran langsung pada pegawai yang tidak memanfaatkan waktu kinerjanya untuk menyelesaikan tugas yang dibebankan padanya. Indikator tingkat kehadiran diperoleh nilai 3,74 dengan kriteria baik. Cara meningkatkannya dengan menerapkan peraturan kedisiplinan pegawai negeri sipil sesuai dengan peraturan pemerintahan agar pegawai slalu hadir untuk bekerja.Indikator anggaran yang dibutuhkan diperoleh nilai 3,81 dengan kriteria baik. Cara meningkatkanya pegawai harus menggunakan aggaran sesuai yang dibutuhkannya dengan sebaik mungkin.

Pada dimensi Perilaku Kerja (PK) untuk indikator efesiensi waktu dalam menyelesaikan suatu 
pekerjaan diperoleh nilai 3,90 dengan kriteria baik. cara meningkatkannya pimpinan harus memberikan apresiasi kepada pegawai yang mampu menyelesaikan suatu pekerjaannya dengan baik. Indikator tingkat sistem jam kerja diperoleh nilai 3,39 dengan kriteria cukup baik. Cara mengatasinya pimpinan harus menerapkan peraturan bagi pegawai yang tidak mengikuti apel pagi dan sore agar pegawai dapat mengikuti apel tersebut.

Dalam hal ini dapat dilihat bahwa kinerja pegawai pada Kantor Badan Pertanahan Nasional Kota Pematangsiantar sudah dikategorikan baik. Walaupun sudah dikategorikan baik, para pegawai dan pimpinan harus meengikuti aturan Sasaran Kinerja Pegawai (SKP), yaitu Peraturan Pemerintah Republik Indonesia No. 46 Tahun 2011 tentang penilaian prestasi kerja pegawai negeri sipil. Penilaian prestasi kerja tersebut terdiri dari dua unsur, yaitu Sasaran Kinerja Pegawai (SKP) dan Perilaku Kerja (PK).

\section{KESIMPULAN DAN SARAN}

\section{Kesimpulan}

Berdasarkan seluruh uraian yang telah dikemukakan dalam bab sebelumnya, maka penulis menarik kesimpulan yaitu sebagai berikut:

1. Hasil analisis deskriptif kualitatif tentang disiplin kerja memiliki nilai rata-rata keseluruhan 3,96 dengan kriteria baik. Nilai rata-rata disiplin kerja tertinggi sebesar 4,23 pada dimensi menjauhi larangan, seperti memiliki barang-barang milik negara secara tidak sah, bertindak sewenang-wenang terhadap bawahan dan membuat keputusan yang menguntungkan salah satu calon peserta pemilu. Nilai rata-rata disiplin kerja terendah sebesar 3,39 pada dimensi menjalankan kewajiban, seperti menaati ketentuan jam kerja, memberikan pelayanan yang baik kepada masyarakat dan menaati peraturan kedinasan.

2. Hasil analisis deskriptif kualitatif tentang komunikasi memiliki nilai rata-rata keseluruhan 3,98 dengan kriteria baik. Nilai rata-rata tertinggi sebesar 4,19 pada dimensi komunikasi ke atas, seperti menyampaikan gagasan, menginformasikan laporan kinerja, dan pada dimensi komunikasi horizontal, seperti kerja sama. Nilai rata-rata komunikasi terendah sebesar 3,74 pada dimensi komunikasi ke bawah seperti, mengkomunikasikan hasil kinerja.

3. Hasil analisis deskriptif kualitatif tentang kinerja pegawai memiliki nilai rata-rata keseluruhan 4,12 dengan kriteria baik. Nilai rata-rata tertinggi sebesar 4,32 pada dimensi sasaran kinerja pegawai (SKP) seperti, pertanggungjawaban hasil kerja, tingkat mutu hasil kerja, efisiensi waktu dalam pekerjaan dan mengalokasikan biaya. Sedangkan nilai rata-rata terendah sebesar 3,39 pada dimensi perilaku kerja (PK) seperti, tingkat sistem jam kerja dalam kegiatan-kegiatan tertentu, misalnya pada saat apel pagi dan sore.
4. Hasil analisis regresi diperoleh persamaan berikut: $\hat{Y}=34,319+0,445 \mathrm{X}_{1}+0,638 \mathrm{X}_{2}$ artinya terdapat pengaruh yang positif antara disiplin kerja $\left(\mathrm{X}_{1}\right)$ dan komunikasi $\left(\mathrm{X}_{2}\right)$ terhadap kinerja pegawai (Y) pada Kantor Badan Pertanahan Nasional (BPN) Kota Pematangsiantar.

5. Hasil analisis koefisien korelasi diperoleh nilai $(r)=0,826$ yang artinya terdapat hubungan yang sangat kuat dan positif antara disiplin kerja dan komunikasi terhadap kinerja pegawai Kantor Badan Pertanahan Nasional (BPN) Kota Pematangsiantar sesuai dengan kriteria koefisien korelasi pada tabel 5. Kemudian diperoleh nilai koefisien determinasi $(R)=0,682$ artinya tinggi rendahnya kinerja pegawai dapat dijelaskan sebesar $68,2 \%$ oleh disiplin kerja dan komunikasi, selebihnya $31,8 \%$ dijelaskan oleh faktor-faktor lain seperti motivasi, kompensasi, lingkungan kerja, kinerja, komunikasi dan faktor-faktor lain yang tidak dibahas dalam penelitian ini.

6. Hasil pengujian hipotesis diperoleh $F_{\text {hitung }}$ sebesar 29,958 $>F_{\text {tabel }}(0,05 ; 2 ; 28)$ sebesar 3,34 atau dengan taraf signifikansi $0,000<\alpha=0,05$ maka $\mathrm{H}_{0}$ ditolak, artinya disiplin kerja dan komunikasi berpengaruh positif dan signifikan terhadap kinerja pegawai pada Kantor Badan Pertanahan Nasional (BPN) Kota Pematangsiantar.

7. Hasil analisis perkiraan nilai variabel disiplin kerja diperoleh $\mathrm{t}_{\text {hitung }}$ sebesar 3,443 $>\mathrm{t}_{\text {tabel }}$ dengan $\mathrm{df}=\mathrm{n}-\mathrm{k}-1 \quad(31-2-1=28)$ sebesar 2,048, atau dengan taraf signifikansi $0,002<\alpha=0,05$ maka $\mathrm{H}_{0}$ ditolak, artinya disiplin kerja berpengaruh positif dan signifikan terhadap kinerja pegawai pada Kantor Badan Pertanahan Nasional (BPN) Kota Pematangsiantar. Sedangkan $t_{\text {hitung }}$ pada variabel Komunikasi $\left(\mathrm{X}_{2}\right)$ sebesar 2,445 $>\mathrm{t}_{\text {tabel }}$ dengan $\mathrm{df}=\mathrm{n}-\mathrm{k}-1 \quad(31-2-1=28)$ sebesar 2,048, atau dengan taraf signifikansi $0,021<\alpha=0,05$ maka $\mathrm{H}_{0}$ ditolak, artinya komunikasi berpengaruh positif dan signifikan terhadap kinerja pegawai pada Badan Pertanahan Nasional Kantor Kota Pematangsiantar.

\section{Saran}

Berdasarkan kesimpulan di atsa, maka perlu dikemukakan beberapa saran yang dapat berguna bagi perusahaan yaitu sebagi berikut:

1. Untuk meningkatkan disiplin kerja pada Kantor Badan Pertanahan Nasional (BPN) Kota Pematangsiantar sebaiknya pemimpin lebih tegas memberikan sanksi seadil-adilnya bagi siapa saja yang melanggar aturan.

2. Untuk meningkatkan komunikasi pada Kantor Badan Pertanahan Nasional (BPN) Kota Pematangsiantar, pimpinan maupun para bawahan harus selalu berusaha menciptakan hubungan baik agar dapat terciptanya lingkungan kerja yang kondusif.

3. Untuk meningkatkan kinerja pegawai pada Kantor Badan Pertanahan Nasional (BPN) Kota Pematangsiantar sebaiknya pimpinan menerapkan peraturan kedisiplinan pegawai 
negeri sipil sesuai dengan peraturan pemerintahan agar pegawai hadir untuk bekerja dan menerapkan peraturan bagi pegawai yang tidak mengikuti apel pagi dan sore.

4. Sehubungan dengan keterbatasan yang ada pada penulis, penelitian ini terdapat kelemahankelemahan dan belum dapat mengungkapkan seluruh variabel yang dapat mempengaruhi kinerja pegawai pada Kantor Badan Pertanahan Nasional (BPN) Kota Pematangsiantar. Sebagai bahan masukan untuk penelitian selanjutnya, perlu memperbanyak variabel penelitian, seperti motivasi, kompensasi, lingkungan kerja dan lain-lain yang tidak dibuat dalam penelitian ini.

\section{E. DAFTAR PUSTAKA}

Dewi, Sutrisna. 2007. Komunikasi Bisnis. Edisi pertama. Yogyakarta: Andi.

Gomes, Faustino Cardoso. 2003. Manajemen Sumber Daya Manusia. Yogyakarta: Andi.

Handoko, T. Hani. 2009. Manajemen. Edisi Kedua. Yogyakarta: BPFE.

Mangkunegara, A. A. Anwar Prabu. 2001. Manajemen Sumber Daya Manusia Perusahaan. Bandung: PT Remaja Rosdakarya Offset.

Mondy, Wayne R. 2008. Manajemen Sumber Daya Manusia. Jakarta: Erlangga.

Noe, A. Raymond, John et. al. 2010. Manajemen Sumber Daya Manusia. Jakarta: Salemba Empat.
Purwanto, Djoko. 2006. Komunikasi Bisnis. Jakarta: Erlangga.

Rivai, Veithzal. 2005. Manajemen Sumber Daya Manusia Untuk Perusahaan dari Teeori ke Praktik. Jakarta: PT Raja Grafindo Persada.

Saydam, Gouzali. 2000. Manajemen Sumber Daya Manusia (Human Resources Management). Jakarta: Djambatan.

Simbolon, Hotman. 2009. Statistika. Edisi Pertama. Yogyakarta: Graha Ilmu.

Sutrisno, DR. Edy. 2009. Manajemen Sumber Daya Manusia. Edisi Pertama. Jakarta: Kencana. 